\title{
PERSEPSI GURU TERHADAP PENILAIAN AUTENTIK KURIKULUM 2013 DI SMPN 3 KOMODO LABUAN BAJO MANGGARAI BARAT
}

\author{
Vinsensius Zwei De Orans Jemalu, Heri Kurnia, \& Triwahyu Budiutomo \\ Universitas Cokroaminoto Yogyakarta \& IKIP PGRI Wates \\ herikurnia312@gmail.com
}

\begin{abstract}
Abstrak
Pendidikan adalah suatu proses bagi peserta didik sebagai generasi penerus bangsa dimasa depan, yang memiliki rasa kebangsaan, dan cinta tanah air. Sehingga sumber daya manusia yang mampu bersaing di era global. Kurikulum 2013 merupakan kurikulum yang menggantikan "Kurikulum Tingkat Satuan Pendidikan (KTSP) 2006". Salah satu standar penilaian pada kurikulum 2013 adalah penilaian autentik. Penilaian autentik merupakan suatu sistem penilaian pada kurikulum 2013 yang komprehensif dalam menjelaskan dan menggambarkan secara detail hasil belajar siswa. Sistem penilaian ini telah dilaksanakan di Sekolah Menengah Pertama Negeri 3 Komdo Labuan Bajo, tetapi penilaia ini masih belum terlaksana dengan sempurna. Oleh karena itu, peneliti ingin mengetahui lebih jauh tentang pelaksanaan sistem penilaian untuk guru, serta kendala yang dihadapinya. Penelitian ini bertujuan untuk mendeskripsikan penerapan penilaian autentik serta kendala yang dialami oleh guru. Hasil penelitian menunjukkan bahwa kendala yang dihadapi oleh guru diantaranya: (1) Kegiatan pelatihan dan kesempatan mengikuti seminar tentang persepsi guru terhadap penilaian autentik kurikulum 2013 yang belum merata. (2) Belum mampu mengelola waktu untuk melakukan penilaian sesuai dengan tuntutan kurikulum. (3) Kurang lengkap jenis penilaian yang digunakan. (4) Belum terbiasa menyusun rubrik penilaian.
\end{abstract}

Kata Kunci: Penilaian autentik, kurikulum 2013, Sekolah Menengah Pertama.

\begin{abstract}
Education is a process for learners as the next generation of the nation in the future, who have a sense of nationality, and love of the homeland. So that human resources are able to compete in the global era. Curriculum 2013 is a curriculum that replaces "Education Unit Level Curriculum (KTSP) 2006". One of the assessment standards in the 2013 curriculum is authentic assessment. Authentic assessment is an assessment system in the 2013 curriculum that is comprehensive in explaining and describing in detail the student's learning outcomes. This assessment system has been implemented at Sekolah Menengah Pertama Negeri 3 Komdo Labuan Bajo, but this assessment is still not implemented perfectly. Therefore, researchers want to know more about the implementation of the assessment system for teachers, as well as the obstacles they face. This study aims to describe the application of authentic assessments as well as the obstacles experienced by teachers. The results showed that the obstacles faced by teachers include: (1) Training activities and the opportunity to attend seminars on teacher perception of authentic assessment of the 2013 curriculum that has not been evenly distributed. (2) Not yet able to manage the time to conduct assessments in accordance with the demands of the curriculum. (3) Incomplete type of assessment used. (4) Not yet used to compiling assessment rubrics.
\end{abstract}

Keywords: Authentic assessment, curriculum 2013, Junior High School.

\section{PENDAHULUAN}

Pendidikan adalah proses dimana suatu bangsa mempersiapkan generasi mudanya untuk menjalankan kehidupan, memiliki rasa kebangsaan, dan cinta tanah air (Irianto, 2011: 1). Penyelenggaraan pendidikan diharapkan dapat mewujudkan proses berkembangnya kualitas pribadi peserta didik sebagai generasi penerus bangsa di masa depan, yang diyakini akan menjadi faktor determinan bagi tumbuh kembangnya bangsa dan negara Indonesia sepanjang zaman.

Memasuki abad ke-21, sistem pendidikan nasional menghadapi tantangan yang sangat kompleks dalam 
menyiapkan kualitas sumber daya manusia (SDM) yang mampu bersaing di era global. Upaya yang tepat untuk menyiapkan sumber daya manusia (SDM) yang berkualitas dan satu-satunya wadah yang dapat dipandang dan berfungsi sebagai alat untuk membangun SDM yang bermutu tinggi adalah melalui pendidikan. Salah satu tuntutan dan tantangan yang dihadapi dunia pendidikan pada saat ini dan ke depan adalah pendidikan hendaknya mampu menghasilkan sumber daya manusia yang memiliki kompetensi yang utuh yaitu kompetensi sikap, kompetensi pengetahuan, dan kompetensi ketrampilan yang terintegrasi.

Berdasarkan Peraturan Pemerintah Nomor 32 Tahun 2013 tentang perubahan atas Peraturan Pemerintah Nomor 19 Tahun 2005 tentang Standar Nasional Pendidikan dijelaskan bahwa penilaian hasil belajar oleh pendidik dilakukan secara berkesinambungan untuk memantau proses, kemajuan belajar dan perbaikan hasil belajar siswa secara berkelanjutan yang digunakan untuk menilai pencapaian kompetensi siswa, bahan penyusunan laporan kemajuan hasil belajar dan memperbaiki proses pembelajaran. Sistem penilaian dalam kurikulum 2013 kemudian dikenal dengan sebutan penilaian autentik (Nurgiansah, 2021a).

Fokus penilaian autentik dalam kurikulum 2013 adalah keberhasilan belajar siswa dalam mencapai standar kompetensi yang ditentukan, meliputi sikap, keterampilan dan pengetahuan. Pencapaian kompetensi siswa benar-benar terukur dan empiris, oleh karena itu harus ada rumusan yang jelas tentang kriteria kompeten tersebut. Berikut adalah kriteria kompeten yang harus dicapai oleh siswa, antara lain:

1. Siswa mampu memahami konsep yang mendasari standar kompetensi yang harus dikuasai.
2. Siswa mampu melakukan pekerjaan sesuai dengan standar kompetensi yang harus dicapai dengan prosedur yang benar dan hasil yang baik.

3. Siswa mampu mengaplikasikan kemampuannya dalam kehidupan sehari-hari. (Yobali Ani, 2013: 1).

4. Siswa dapat dikatakan kompeten setelah dilakukan penilaian dengan instrumen yang benar-benar kompeten secara nyata dan relative permanen/tetap, sehingga informasi yang diberikan benar-benar akurat. Pencapaian kompetensi siswa adalah sesuatu yang terukur, operasional dan siswa mengalami secara pribadi di dalam proses pembelajaran tersebut.

5. Penilaian autentik adalah penilaian yang dilakukan mencakup kompetensi sikap, keterampilan dan pengetahuan selama proses pembelajaran berlangsung. Guru harus merancang instrumen penilaian sesuai dengan kompetensi yang ingin dicapai dari mata pelajaran dan dapat diaplikasikan dalam kehidupan seharihari.

6. Kurikulum 2013 menekankan pada dimensi pedagogik modern dalam pembelajaran, yaitu menggunakan pendekatan ilmiah (scientific approach). Pendekatan ilmiah dalam pembelajaran sebagaimana dimaksud meliputi kegiatan mengamati, menanya, menalar, mencoba, dan membentuk jejaring untuk semua mata pelajaran.

Salah satu standar penilaian pada kurikulum 2013 yakni penilaian autentik. Pada kurikulum 2013, penilaian autentik yang diterapkan mencakup semua aspek yakni aspek sikap, pengetahuan, dan keterampilan. Pengukuran yang bermakna secara signifikan atas hasil belajar peserta didik untuk ranah sikap, keterampilan, dan pengetahuan (Kemendikbud, 2013: 240).

Diberlakukan dan dilaksanakan sistem penilaian autentik merupakan suatu harapan besar akan keberhasilan 
peningkatan mutu pendidikan, khususnya prestasi hasil belajar siswa, yang selanjutnya diharapkjan akan meningkatkan mutu pendidikan nasional.

Alasan utama diberlakukan sistem penilaian autentik karena penilaian dapat digunakan untuk mengetahui kekuatan dan kelemahan dalam proses pembelajaran, sehingga dapat dijadikan dasar dalam pengambilan keputusan, dan perbaikan dalam sebuah proses pembelajaran (Kunandar, 2014: 30).

Namun pada kenyataan di lapangan, penilaian hasil belajar yang dilakukan oleh guru hanya dari segi pengetahuan saja. Guru mengukur keberhasilan belajar siswa dengan tes tertulis, untuk mengukur sejauh mana siswa memahami materi yang sudah diajarkan oleh guru. penilaian hanya terfokuskan pada kompetensi pengetahuan siswa, sedangkan sikap dan keterampilan siswa selama proses pembelajaran berlansung tidak dinilai. Sehingga terlihat, pencapaian kompetensi pengetahuan dari siswa adalah paling utama.

\section{METODE PENELITIAN}

Penelitian ini menggunakan pendekatan penelitian kualitatif dan jenis penelitiannya yaitu deskripsi analisis berupa data tertulis dengan mendeskripsikan kembali data yang terkumpul dari objek penelitian. Untuk memperoleh data, peneliti menggunakan metode pengumpulan data dengan dua cara, yakni kepustakaan (library research) dan penelitian lapangan (field research) (Nurgiansah, 2021c).

Sedangkan metode pembahasan dalam penelitian ini menggunakan metode deskriptif analisis yaitu peneliti menggambarkan permasalahan dengan didasari pada teori-teori penilaian autentik kurikulum 2013 dan teori persepsi guru tentang penilaian autentik kurikukum 2013. Lalu di analisis lebih lanjut untuk kemudian diambil kesimpulan.
Penelitian ini bertempat di SMP Negeri 3 Komodo Labuan Bajo, Kecamatan Komodo, Kabupaten Manggarai Barat, Provinsi Nusa Tenggara Timur (NTT). Penelitian ini dilaksanakan pada Tahun 2020, yaitu dari tanggal 22 April sampai dengan tanggal 10 Juni 2020. Dalam penelitian ini yang menjadi subjek penelitian adalah guru-guru di SMPN 3 Komodo Labuan Bajo. Sedangkan yang menjadi objek penelitiannya adalah persepsi guru SMPN 3 Komodo Labuan Bajo terhadap sistem dan pelaksanaan penilaian autentik kurikulum 2013.

\section{HASIL PENELITIAN DAN PEMBAHASAN Hasil Penelitian}

SMP Negeri 3 Komodo Labuan Bajo ini, didirikan pada tanggal 03 Agustus 2010 dengan izin pendirian sekolah nomor 134/KEP/HK/2010 dan izin operasional tanggal 03 Agusustus nomor 134/KEP/HK/2010 di kecamatan Komodo, Kabupaten Manggarai Barat, yang terletak $6 \mathrm{~km}$ dari pusat kota Labuan Bajo. Dalam perkembangan selanjutnya agar pendirian sekolah ini memiliki legalitas hukum, maka sekolah ini dikelola oleh Pemerintah Daerah (PEMDA) Labuan Bajo. Seiring dengan perkembangan zaman dan sesuai dengan tuntutan global, maka SMP Negeri 3 Komodo harus mampu menghasilkan daya saing yang tinggi.

A. Visi SMP N 3 Komodo Labuan Bajo

Terwujudnya sekolah sebagai unit layanan jasa pendidikan yang mampu mengembangkan potensi siswa secara maksimal yang dijiwai oleh nilai-nilai budaya dan karakter bangsa melalui pengembangan standar Nasional Pendidikan.

B. Misi SMP N 3 Komodo Labuan Bajo

a. Mewujudkan pengembangan dan pelaksanaan proses belajar yang aktif, inovasif, kreatif, dan menyenangkan. 
b. Mewujudkan kegiatan pembinaan kesiswaan berbasis pendidkan budaya Dan karakter bangsa.

c. Mewujudkan Standar hasil Lulusan yang mempunyai kompetensi tinggi Secara kuantintas dan kualitas.

d. Mewujudkanpengembangan profesionalisme pendidik dan tenaga kependidikan sesuai dengan kompetensinya.

e. Mewujudkan pengembangan sarana dan prasarana sesuai dengan standar Sarana dan prasarana termasuk perangkat dan jaringan teknologi informasi Dan komunikasi.

f. Mewujudkan pelaksanaan manajemen berbasis sekolah dengan mengedepankan prinsip-prinsip partisipasi, transparasi dan akuntabilitas.

C. Kegiatan Ekstrakurikuler SMP N 3 Komodo Labuan Bajo

Disamping fokus terhadap pelajaran sekolah juga mendorong sepenuhnya bakat dan minat pada siswa di bidang lain. Kegiatan ekstrakurikuler diarahkan untuk memberi pengalaman kepada siswa untuk mencoba hal-hal baru dan berinteraksi dengan masyarakat baik melalui lomba-lomba maupun kegiatan sosial lainnya.

D. Sarana dan Prasarana SMP N 3 Komodo Labuan Bajo

Ruangan belajar SMPN 3 Komodo Labuan Bajo

1. Ruang kelas yang tersedia 9 ruang.

2. Ruang kelas terpakai 8 ruang

3. Perpustakaan 1 ruang

4. Laboratorium 1 ruang

5. Kantor 1 ruang

6. Ruang guru 1 ruang

Adapun keadaan ruang belajar dan jumlah siswa di SMP Negeri 3 Komodo, Labuan Bajo Kecamatan Komodo, Manggarai Barat, adalah sebagai berikut:
Tabel 1

Ruangan belajar SMPN 3 Komodo Labuan Bajo, Kecamatan Komodo, Kabupaten Manggarai Barat Tahun 2020/ 2021

\begin{tabular}{|c|c|c|}
\hline No & Ruang Belajar & $\begin{array}{c}\text { Jumlah } \\
\text { Ruang }\end{array}$ \\
\hline 1 & Kelas VII & 2 \\
\hline 2 & Kelas VIII & 3 \\
\hline 3 & Kelas IX & 4 \\
\hline & Jumlah & 8 \\
\hline
\end{tabular}

(Sumber: Dokumentasi SMPN 3 Komodo

Labuan Bajo Kecamatan Komodo Manggarai Barat)

Tabel 2

Jumlah siswa SMPN 3 Komodo Labuan Bajo, Kecamatan Komodo, Kabupaten Manggarai Barat Tahun 2020/ 2021

\begin{tabular}{|c|c|c|}
\hline No & Ruang Belajar & $\begin{array}{c}\text { Jumlah } \\
\text { Ruang }\end{array}$ \\
\hline 1 & Kelas VII & 52 \\
\hline 2 & Kelas VIII & 87 \\
\hline 3 & Kelas IX & 62 \\
\hline & Jumlah & 201 \\
\hline
\end{tabular}

(Sumber: Dokumentasi SMPN 3 Komodo

Labuan Bajo Kecamatan Komodo Manggarai Barat)

E. Model Kurikulum di SMP N 3 Komodo Labuan Bajo

Secara umum model kurikulum yang digunakan oleh SMPN 3 Komodo Labuan Bajo adalah menggunakan kurikulum 2013. Kurikulum ini merupakan kurikulum operasional yang disusun dan dilaksanakan dimasingmasing satuan pendidikan. Sedangkan pemerintah pusat hanya memberi rambu-rambu yang perlu dirujuk dalam pengembangan kurikulum. Jadi pada kurikulum ini sekolah sebagai satuan pendidikan guru hanya siap mengajar karena RPP telah dibuat oleh pemerintah pusat dan itu semua juga telah menyusun dan membuat silabus pendidikan sesuai dengan kepentingan 
siswa berdasarkan pada pelaksanaan, maka siswa juga diberi kesempatan untuk memperoleh pengetahuan secara terbuka berdasarkan sistem ataupun silabus yang telah ditetapkan masingmasing sekolah.

Tujuan pengembangan kurikulum adalah untuk menghadapi persaingan global yang semakin maju, menciptakan lulusan yang memiliki kemampuan yang berkomunikasi, berpikir kritis dan jernih, menciptkan lulusan yang memiliki kemampuan mempertimbangkan segi moral suatu permasalahan, menciptakan lulusan yang mampu menjadi Warga Negara yang bertanggung jawab, menciptakan lulusan yang memiliki kemampuan dalam bermasyarakat global (Nurgiansah, 2021b).

Kemampuan-kemampuan tersebut diharapkan dapat tercapai dengan penerapan kurikulum 2013. Berbagai keluhan dan kesulitan yang timbul di sekolah kemungkinan terjadi karena belum terbiasanya penerapan kurikulum tersebut dalam proses pembelajaran. Penerapan secara konsisten sangat diharapkan agar mencapai tujuan dan alasan pemerintah mengembangkan kurikulum baru.

F. Sistem dan Pelaksanaan Penilaian Autentik di SMP N 3 Komodo Labuan Bajo

Ada tiga tipe penilaian siswa yang berbeda dan memiliki sasaran masingmasing, yaitu:

1. Penilaian atas pembelajaran (atau penilaian sumatif), merangkum pencapaian siswa pada akhir tahun ajaran. Penilaian ini memonitor seberapa baik siswa telah belajar apa yang diajarkan guru dan dilaporkan sebagai sebuah angka atau huruf.

2. Penilaian bagi pembelajaran (atau penilaian formatif), memberikan tanggapan deskriptif utuk meningkatkan pembelajaran dan proses pembelajaran. Penilaian ini menolong siswa mengklarifikasi makna dan mengatasi hambatan pembelajaran. Penilaian ini dapat menciptakan kepercayaan diri siswa mengenai kemampuan mereka untuk belajar dan menantang siswa meneruskan serta meningkatkan pembelajaran mereka.

3. Penilaian sebagai pembelajaran, siswa belajar dari menilai kemajuan mereka sendiri. Siswa mempraktekkan penilaian diri sendiri terhadap pembelajaran mereka, pengetahuan, keterampilan, kreativitas dan sifat mereka. Siswa juga belajar menentukan tujuan yang bermakna dan realistis.

\section{Pembahasan}

Penilaian autentik kurikulum 2013 merupakan penilaian yang tepat dan lengkap untuk dapat menilai input, proses, product, output dan outcome (Nurgiansah, 2020). Hal ini sangat sesuai dengan tuntutan penyediaan SDM di era milenial saat ini. Pemahaman guru perlu ditingkatkan, dengan pemahaman yang relatif kurang mengakibatkan pelaksanaannyapun kurang menggembirakan, dalam arti guru belum melaksanakan secara mantap dan maksimal. Belum pahamnya guru tentang penilaian autentik kurikulum 2013 mengakibatkan persepsi guru kurang kuat dan tidak benar. Data menunjukkan lebih dari separoh $(57,14 \%)$ guru berpersepsi kurang kuat dan tidak benar, hal ini merupakan kendala utama kurang berhasilnya secara maksimal penilaian autentik, guru yang kurang begitu paham cenderung memiliki persepsi yang tidak benar.

Persepsi guru tentang sistem dan pelaksanaan penilaian autentik kurikulum 
2013 dapat dikelompokkan menjadi empat kelompok, yaitu:

1. Persepsi Guru Sangat Baik Guru yang telah mengikuti sosialisasi dan pelatihan seperti Guru PPKN, Guru Bahasa Indonesia, Guru Matematika, Guru IPA, Guru IPS, sehingga sangat mengetahuinya tentang penilaian autentik. Berbeda dengan guru yang sama sekali belum mengikuti pelatihan sama sekali tidak mengerti. Guru yang sangat baik itu, guru yang memahami penilaian autentik kurikulum 2013 dan bisa menerapkan dalam pembelajaran, sehingga ada perubahan kepada peserta didik. Setelah kita memahami ciri-ciri dari seorang guru yang sangat baik menjadi guru yang profesional.

Kita tahu bahwa Guru yang sudah sertifikasi maka menjadi guru profesional adalah hal yang wajib. Berikut ini merupakan beberapa dari ciri guru profesional yang mungkin bisa menjadi panutan bagi yang ingin mengembangkan diri agar benar-benar menjadi guru professional dan guru yang sangat baik dalam penilaian autentik. Dibawah ini adalah ciri-ciri guru yang benar- benar memiliki jiwa pendidik atau profesional:

a. Guru harus selalu mempunyai tenaga untuk siswanya. Guru yang baik akan memberi perhatian pada siswa di setiap obrolan atau diskusi yang dilakukan dan punya kemampuan mendengar dengan seksama.

b. Seorang guru harus mempunyai tujuan yang jelas. Ciri guru profesional adalah menetapkan tujuan setiap pelajaran secara jelas dan bekerja guna memenuhi tujuan dalam setiap kelas.

c. Mempunyai keterampilan untuk mendidik agar murid disiplin. Guru harus mempunyai keterampilan disiplin yang efektif. Hal ini agar bisa memberi promosi atas perubahan perilaku positif di dalam kelas.

d. Mempunyai keterampilan untuk memanajemen di dalam kelas yang baik. Guru harus mempunyai keterampilan manajemen di dalam kelas yang baik serta bisa memastikan agar perilaku siswa menjadi baik saat siswa belajar dan bekerja sama.

e. Guru harus bisa berkomunikasi secara baik dengan orang tua murid. Seorang guru harus menjaga komunikasi yang baik dengan orang tua dan bisa membuat mereka selalu mengerti tentang informasi yang sedang terjadi.

f. Guru mempunyai ekspektasi yang tinggi pada muridnya.Guru profesional memiliki ekspektasi besar pada siswa serta memacu semua siswa untuk terus bekerja dan mengerahkan potensi terbaik yang mereka miliki.

g. Mempunyai pengetahuan perihal kurikulum. Guru harus mempunyai pengetahuan yang mendalam mengenai kurikulum sekolah dan standar yang lain. Guru dengan sekuat tenaga akan memastikan bahwa pengajaran yang mereka lakukan sudah memenuhi standarstandar tersebut.

h. Mempunyai pengetahuan mengenai subyek yang diajarkan. Meskipun sudah jelas, namun terkadang diabaikan. Guru profesional memiliki pengetahuan yang sangat baik dan antusiasme terhadap subyek yang diajarkan. Guru tersebutselalu siap untuk menjawab semua pertanyaan dan menyimpan berbahai bahan yang menarik bagi siswa.

i. Guru selalu memberikan yang paling baik bagi anak didik di dalam proses pengajaran. Ciri guru profesional adalah selalubergairah dalam 
mengajar dan bekerja bersama dengan anak didik. Guru akan merasa gembira ketika bisa mempengaruhi siswa dalam kehidupannya dan memahami efek yang mereka miliki.

\section{Persepsi Guru Baik}

Guru yang baik, guru yang dapat menerapkan penilaian autentik di sekolah sehingga dengan mudah peserta didik akan dapat memahami dan bisa melaksanakan kurikulum 2013. guru yang baik harus lebih dalam segala hal dari orang-orang pada umumnya. Harus lebih mengerti, lebih memiliki ilmu pengetahuan, lebih sempurna dari orang-orang lain. Guru harus mampu mengatasi kelemahan manusia lain. Bagaimanapun juga untuk menjadi guru yang baik tidaklah mudah, mereka harus belajar terus menerus dan di dalam dirinya percaya bahwa dirinya belum cukup baik walaupun orang diluar sana banyak yang memuji mereka. Menjadi guru itu tidaklah mudah, karena selama hidupnya mereka harus menggapai sebuah tujuan yang penuh dengan masalah dan rintangan.Terlebih lagi menjadi seorang guru yang baik secara garis besar tugasnya adalah memanusiakan manusia.

Ciri-ciri guru yang baik adalah sebagai berikut:

1. Tenang dan tidak menunjukkan emosi yang menyala.

2. Tidak mempunyai prasangka yang buruk kepada peserta didiknya.

3. Dapat menyembunyikan perasaannya dari peserta didik,

4. Memandang semua peserta didik sama.

5. Mampu menciptakan lingkungan belajar yang menyenangkan, bebas, motivator, dan semangat.

6. Konsisten, tidak berubah-ubah pendirian dan jarang melakukan kesalahan.

7. Pandai,bijaksandalam memperlakukan siswa dan mampu menjawab pertanyaan siswa.
8. Sanggup memberikan bantuan secara maksimal kepada peserta didik.

3. Persepsi Guru yang cukup

Guru yang kurang sosialisa dan pelatihan oleh karena itu betapa pentingnya kesiapan guru dalam mengimplementasi kurikulum 2013 dalam penilaian autentik. Dan pada akhirnya semua akan bergantung pada mutu dan kualitas guru di lapangan. Guru harus selalu berusaha menyusuaikan diri dengan kurikulum yang baru yang dibuat oleh pemerintah, dan pemerintahpun selalu ada sosialisai mengenai pendidikan atau kurikulum 2013 berpacu dalam penilaian autentik. Karena ada banyak guru yang belum bisa menerapkan kurikulum 2013 secara penilaian autentik.

Kebanyakan guru yang telah menerapkan kurikulum 2013 tetapi mereka belum memahami penilaiannya secara autentik yang diterapkan dari kkurikulum 2013. Padahal untuk mengetahui pemetaan kompetensi guru, sarana atau wadah yang paling tepat adalah melalui pelatihan-pelatihan. Hari ini frekuensi pelatihan bagi guru sangat kurang, bahkan dibeberapa daerah justru tidak pernah sama sekali mengadakan pelatihan untuk guru.

Padahal untuk mengetahui pemetaan kompetensi guru, sarana atau wadah yang paling tepat adalah melalui pelatihanpelatihan. Artinya masih banyak guru yang hanya tahu mengajar dan menyajikan materinya tanpa memahami tujuan kurikulum yang diharapkan sehingga jangan pernah salahkan guru apabila ada stigma yang menyatakan walaupun kurikulum berganti tetapi materinya tetap itu-itu saja.

Melalui pelatihan, sehingga kita dapat memahami proses penilaian autentik yang diterapkan oleh kurikulum 2013 sehingga kami sebagai guru dengan mudah memahami dan melaksanakan atau menerapkan proses penilaian autentik 
karena kurikulum ini mengajak peserta didik untuk lebih aktif dalam pembelajaran. Persepsi guru terhadap mata pelajaran pada Kurikulum 2013 menunjukkan bahwa guru di SMPN 3 Komodo Labuan Bajo mendukung sepenuhnya mata pelajaran dikelompokkan menjadi wajib dan peminatan, Kurikulum 2013 dinilai oleh guru sangat lengkap dan lebih rinci, namun tidak diimbangi dengan pelatihan sejak dini sehingga guru mengalami kesulitan dalam mengaplikasikan Kurikulum 2013 dalam proses pembelajaran terutama pada aspek penilaian yang dinilai terlalu rumit.

4. Persepsi Guru yang Kurang

Guru Belum Memahami Penilaian Autentik, memang sekolah sudah menerapkan kurikulum 2013, tapi Kami masih berusaha menyesuaikan dengan kurikulum yang baru ini dengan mempelajari petunjuk-petunjuknya. Namun kami masih belum mengetahui cara penilaian di kelas, serta kesiapan guru dan pemerintah masih kurang dan terkesan mendadak.

Memang tidak semua guru yang belum memahami penilaian autentik yang diterapkan oleh kurikulum 2013 hanya guru yang ikut pelatihan yang memahami, seperti guru PPKN, guru bahasa indonesia, guru matematika, guru IPA, guru IPS, sehingga sedikit mengetahuinya tentang penilaian autentik. Berbeda dengan guru yang sama sekali belum mengikuti pelatihan kurikulum 2013, mereka merasa terombang-ambing dengan keputusan pemerintah tersebut. Sehingga penilaian autentik kurikulum 2013 ini dampak sekali terhadap guru yang belum memahami adalah sebbagai berikut:

a. Guru belum bisa terapkan dalam mata pelajaran.

b. Guru masih menggunakan cara mengajar KTSP.

c. Guru belum bisa menilai peserta didik secara autentik.

\section{KESIMPULAN}

1. Penilaian Autentik

Penilaian autenttik adalah kegiatan menilai peserta didik yang menekankan pada apa yang seharusnya dinilai, baik proses maupun hasil dengan berbagai instrumen penilaian yang disesuaikan dengan tuntutan kompetensi yang ada di Standar Kompetensi (SK) atau Kompetensi Inti (KI) dan Kompetensi Dasar (KD).

Penilaian autentik dalam kurikulum 2013 mengacu pada Permendik-bud Nomor 66 Tahun 2013 tentang Standar Penilaian Pendidikan. Kurikulum 2013 dikembangkan dengan landasan filosofis yang memberi-kan dasar bagi pengembangan seluruh potensi siswa menjadi manusia Indonesia berkualitas.

Standar penilaian bertujuan untuk menjamin: 1) perencanaan penilaian siswa sesuai dengan kompetensi yang akan dicapai dan berdasarkan prinsipprinsip penilaian, 2) pelaksanaan penilaian siswa secara professional, terbuka, edukatif, efektif, efisien dan sesuai dengan konteks sosial budaya, dan 3) pelaporan hasil penilaian siswa secara objektif, akuntabel dan informatif.

Dalam menyusun rencana pembelajaran, guru perlu memperhatikan instrumen penilaian yang digunakan harus memantau proses, kemajuan dan perbaikan hasil belajar siswa secara berkesinambungan. Karena penilaian memiliki makna yang penting, baik bagi siswa, guru maupun sekolah. Penilaian autentik merupakan penilaian yang dilakukan secara terencana, baik mulai dari penentuan instrumen, penyusunan instrumen, telaah instrumen, pelaksanaan penilaian, analisis hasil penilaian dan program tindak lanjut hasil penilaian. Jika hal langkah-langkah tersebut dilakukan dengan baik, maka guru dapat 
meningkatkan mutu hasil belajar siswa dalam pencapaian kompetensi sikap, keterampilan dan pengetahuan secara maksimal setelah siswa selesai mengikuti proses belajar mengajar. Penilaian autentik juga membuat proses pembelajaran lebih menyenangkan. Proses pembelajaran menjadi hidup dan lebih bermakna serta menciptakan hubungan yang interaksi antara guru.

Semangat untuk melaksanakan penilaian autentik sudah baik, hal ini dapat dilihat dari adanya dampak positif bagi guru dan siswa, karena pada dasarnya penilaian autentik menilai dari aspek pengetahuan, sikap dan keterampilan. Apalagi dukungan pengelola sekolah sangat baik, dalam hal ini walaupun pada pelaksanaannya para guru mengalami kendala, namun pihak sekolah selalu mengusahakan untuk mengatasi kendala tersebut. Salah satu upaya dinas pendidikan dan pihak sekolah adalah dengan mengadakan pelatihan yang di ikuti oleh guru agar bisa memastikan kendala yang dihadapi oleh guru dan mencari solusi bersama.

2. Persepsi guru terhadap sistem dan pelaksanaan penilaian autentik kurikulum 2013 masuk pada kriteria cukup cenderung kurang baik.
3. Adanya persepsi guru dan siswa yang kurang baik lebih disebabkan karena beberapa kendala sebagai berikut:

a. Pemahaman guru tentang sistem dan pelaksanaan penilaian autentik masih kurang. Hal ini menyebabkan guru belum paham sepenuhnya tentang kurikulum 2013. Sebagaimana kita ketahui bahwa dalam kurikulum 2013 guru menjadi fasilitator, namun yang terjadi adalah guru tidak membimbing siswa dan hanya memberi tugas tanpa ada pendamping untuk siswa, guru tidak mengunakan metode scientific approach dan mengunakan metode ceramah bervariasi karena menganggap metode ceramah bervariasi masih cocok untuk siswa.

b. Siswa yang belum siap menggunakan kurikulum 2013, diakibatkan terlalu lama menggunakan KTSP sehingga para siswa lambat menyesuaikan diri dengan kurikulum 2013. Para siswa masih bersifat pasif yaitu masih mengharapkan guru sebagai satusatunya sumber pengetahuan siswa dan hal ini juga menyebabkan guru masih menggunakan ceramah bervariasi dalam pembelajaran, para siswa jadi jenuh karena terlalu banyak tugas yang dibebankan kepada mereka.

\section{DAFTAR PUSTAKA}

Adam I. Indra Wijaya, 2002. Prilaku Organisasi. Bandung; Sinar Baru Algesindo.

Heri Kurnia, A. N. (2021). Model Perencanaan Pembelajaran PPKn Berbasis Literasi. Jurnal Basicedu, 5(2), 733-740. doi:https://doi.org/10.31004/basicedu.v5i2.794

Hidayat, 2013. Pengembangan Kurikulum Baru. Bandung; PT.Remaja Rosdakarya Bandung. Hilda Taba, 2009. Kurikulum dan Pengaruh, Jakarta, Sinar Grafika Offset.

Igbal, Hasan. 2002. Pokok-Pokok Materi Metodologi Penelitian dan Aplikasinya. Ghalia Indonesia.

Irianto, Jusuf, 2011. Sumber Daya Manusia Sektor Publik di Indonesia; Pengantar Model SDM

Sektor Publik. Jurnal MSDM Surabaya; Departemen Administrasi.

KBBI, Edisi Keempat, 2008. Gramedia Pustaka Utama, Jakarta. 
Kemendikbud, 2013. Peraturan menteri pendidikan dan kebudayaan RepublicIndonesia No 68 tahun 2013 tentang kerangka dasar dan struktur kurikulum SMP/MTs. Dokumen. Jakarta; Kemendikbud.

Kemendikbud 2013 No. 69 Tahun 2013. Tentang KD dan Struktur KurikulumSMA/MA Jakarta; Menteri Pendidikan dan Kebudayaan Republik Indonesia.

Kemendikbud, 2013. Penilaian Pendidikan. Jakarta; Kementrian Pendidikan dan Budaya.

Kunandar, 2014. Penilaian autentik (Penilaian hasil belajar peserta didik berdasarkan kurikulum 2013) Edisi Revisi, Jakarta : PT. Raja.

Moleong, 2011. Metodologi Penelitian Kualitatif, Edisi Revisi. Bandung; PT Remaja Rosdakarya.

Mulyasa, 2013. Pengembangan dan Implementasi kurikulum 2013. Bandung, PT.Remaja Rosdakarya.

M. Sukarjo,dkk.,2009. Landasan Pendidikan Konsep dan Aplikasinya, Jakarta : Rajawali Pers, 2013.

Nurgiansah, T. H. (2020). Filsafat Pendidikan. In Banyumas: CV Pena Persada.

Nurgiansah, T. H. (2021a). Partisipasi Politik Masyarakat Sleman di Masa Pandemi Covid-19 dalam Konteks Pendidikan Kewarganegaraan. Jurnal Civic Hukum, 6(1), 1-9.

Nurgiansah, T. H. (2021b). Pendidikan Pancasila. In Solok: CV Mitra Cendekia Media.

Nurgiansah, T. H. (2021c). Workshop Media Pembelajaran Berbasis Teknologi Informasi Dalam Menghadapi Revolusi Industri 4.0. Jurnal Pengabdian Untuk Mu NegeRI, 5(1), 1-4.

Poerwati,dkk, 2013. Panduan Memahami Kurikulum 2013 Sebuah InovasiStruktur Kurikulum Penunjang Pendidikan MasaDepan. Jakarta; Prestasi Pustakarya.

Sayuti, Husein. 1989. Pengantar Metodologi Riset, Jakarta; Fajar Agung.

Supardi, $\quad$ t.th., Penilaian autentik (Pembelajaran afektif, kognitif, danPsikomotor): Konsep dan Aplikasi.

Usman, 2008. Manajemen, Teori, Praktik, dan Riset Pendidikan. EdisiKedua, Jakarta; Bumi Aksara.

Walgito, 2002. Psikologi umum (Yogyakarta; Andi).

Zainudin Bakar, A. N. (2021). IMPLEMENTASI KURIKULUM 2013 MATA PELAJARAN PENDIDIKAN PANCASILA DAN KEWARGANEGARAAN DI SMP NEGERI MURIABANG KABUPATEN ALOR. Jurnal PPKn, 52-63. 